Article

\title{
Strategies of Forestry Carbon Sink under Forest Insurance and Subsidies
}

\author{
Ye Song and Hongjun Peng * \\ College of Economics and Management, Nanjing Forestry University, Nanjing 210037, China \\ * Correspondence: penghj@njfu.edu.cn; Tel.: +86-138-1338-8466
}

Received: 12 July 2019; Accepted: 22 August 2019; Published: 24 August 2019

check for updates

\begin{abstract}
We take the forest insurance supply chain, composed of a forestry enterprise and an insurance company, as the research object. The forestry carbon sink, operated by the forestry enterprise, is the subject matter of insurance. The Stackelberg game model is constructed to study the optimal strategies of the forestry enterprise and insurance company under the forest insurance mechanism, as well as the impact of government subsidies, probability of deforestation, and carbon limit level on the decision-making and profit of the forestry enterprise and insurance company. The results show that the larger the carbon limit, the looser carbon restraint policy, which causes the forestry enterprise to reduce the scale of carbon sink forest, and the insurance company lowers the premium level. As the probability of deforestation increases, both the scale of the carbon sink forest and the premium level will decrease. Direct subsidies for the premiums of the forestry enterprise are conducive to expanding the scale of carbon sink forest, but will lead to the insurance company improving the premium level. Providing indirect subsidies to the insurance company's operating costs will not only expand the scale of the carbon sink forest, but also lower the premium level. In the case of the same number of premium subsidies, indirect subsidies are more effective than direct subsidies in increasing the forestry enterprise's income and promoting it to expand the forest scale.
\end{abstract}

Keywords: forestry carbon sink; forest insurance; insurance subsidy; sustainable development

\section{Introduction}

As climate warming is considered to be intensifying, countries around the world are committed to exploring effective measures to mitigate climate change. Forests are the mainstay of terrestrial ecosystems that can sequester large amounts of carbon from the atmosphere [1,2]. The use of forestry carbon sequestration is less economical than the enterprise's ability to reduce emissions through technology, which has greater potential to alleviate climate warming and promote sustainable human development $[3,4]$. Expanding forest area and promoting forest growth through artificial activities, such as afforestation and management, have significant potential for emission reduction [5-9]. In the United States, for example, forest resources in its territory can offset one-eighth annual carbon dioxide emissions in the country [10]. Based on scenario paths, some scholars have pointed out that as forests continue to expand and woods continue to rise in energy consumption, no other emission reduction measures are needed in the future except forestry carbon sinks [11]. Therefore, scholars believe that forestry carbon sinks are the key to addressing urgent global issues such as climate change and energy shortages [12].

Forests are vulnerable to various natural disasters and human activities. The deterioration of soil and climatic conditions, aging of trees, and improper logging can cause great damage to forest growth [13-20], which affects carbon sequestration in forests and reduces the output of forestry carbon sinks. As one of the important measures to enhance the risk resistance ability of forestry, forest 
insurance can ensure the rapid recovery of forestry production and operation after the disaster, reduce the risk of forestry investment and financing, and promote the sustainable operation of forestry.

Some researchers studied the role of insurance system in increasing forestry carbon sink output. Subak et al. [21] emphasized that insurance plays an important role in bridging forestry carbon losses and protecting the sustainable export of forestry carbon sink. However, the existing insurance contract for protecting forestry carbon sink is insufficient, and innovations in insurance content and method are needed. Hartebrodt et al. [22-24] studied the pricing of forestry carbon sink insurance from climate change trends and carbon price fluctuations. They found that various factors need to be considered when pricing insurance, such as disaster risk and forestry enterprise's willingness to pay for the insurance. Cairns and Lasserre [25] believed that forestry carbon sink management is an act which is under the risk of multiple climate disasters. Once the risk occurs, the entire insurance system will suffer great losses. Strengthening the construction of forestry carbon sink trading market and insurance market through effective government guidance policies (carbon limit policy, forestry carbon sink project financing policy, etc.) can minimize risks. However, there are no in-depth researches or discussions on how risk of disaster, forest management cost, carbon limit level, and government subsidies affect the decisions of forest enterprises and insurance companies.

It is clear that government subsidies can enhance the willingness of forestry enterprises and insurance companies to participate in forestry carbon sink insurance. However, the standards and quotas of subsidy for forest insurance are still insufficient compared with agricultural insurance. Thus, the government needs to further expand the category and scope of forestry subsidies [26-28]. Some scholars analyzed how to improve the subsidy efficiency of forest insurance and found that a single increase in the proportion of insurance subsidies can indeed enhance the willingness of forest owners to purchase insurance, but it also leads to the poor efficiency of subsidy [29-31]. The effective insurance needs, types of disasters, development level of the insurance industry, and dependence on subsidies in different areas vary highly. These factors will affect the efficiency of government subsidies. So, it is necessary to implement differentiated premium subsidy policies and establish a multilevel subsidy system [32,33]. There are few studies on indirect subsidies (subsidies for insurance companies). These researchers emphasized that to stimulate insurance companies to innovate forest insurance products and increase insurance supply, the government should take measures such as subsidizing the insurance company's business expenses and giving it certain tax preferences [34-36]. Overall, the current papers on how to improve the efficiency of direct subsidies (subsidies to forestry enterprises) are still based on qualitative discussion, which inevitably can be driven either by the personal subjectivity of researchers or by organized interests. To the best of our knowledge, researches that compare the efficiency of direct subsidies and indirect subsidies have not been documented.

Based on the above research review, we study an insurance contract supply chain consisting of a single forestry enterprise and a single insurance company (as can be seen in Figure 1). Two types of subsidies are compared: Subsidizing the insurance premiums of the forestry enterprise (direct subsidies) and subsidizing the operating expenses of the insurance company (indirect subsidies). The forestry enterprise signs the forestry carbon sink insurance contract with the insurance company. By constructing the Stackelberg game model, we explore the decision-making of the scale of the carbon sink forest of forestry enterprise and the premium of the insurance company under the insurance mechanism, as well as analyze the impact of insurance subsidies and carbon limit levels on decision-making and profits of forest enterprise and insurance company. We also compare the efficiency of direct subsidies and indirect subsidies. 


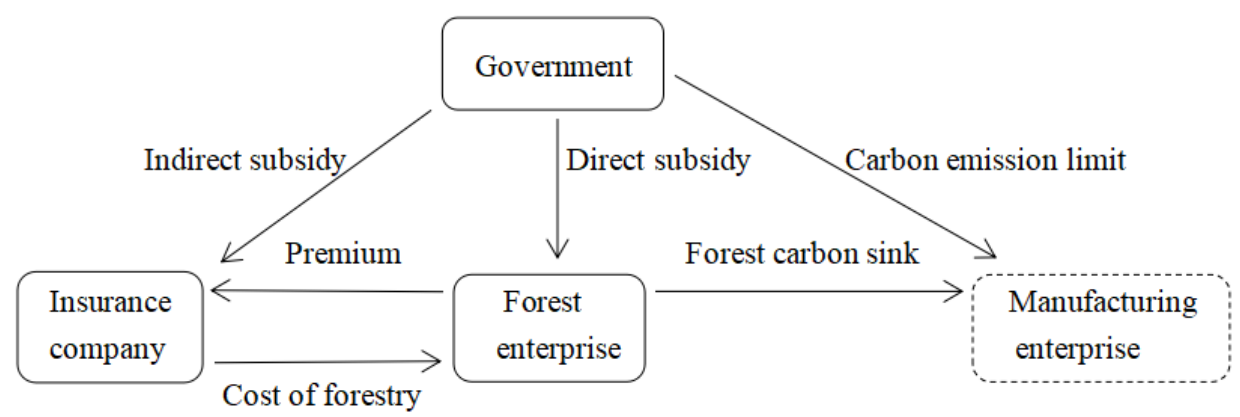

Figure 1. Forestry carbon sinks insurance contract supply chain.

The main innovations and contributions of this paper are as follows. First, we study the carbon sink forest management strategy under the forest insurance mechanism and explore the impact of various factors, such as government subsidies, carbon limit level on the decision-making, and profit of forestry enterprise and insurance company. Second, we compare the efficiency of the direct subsidies to the forestry enterprise and the indirect subsidies to the insurance company. It is concluded that under the same amount of subsidy, indirect subsidies are more efficient in increasing the income of the forestry enterprise.

\section{Assumptions and Parameter Settings}

\subsection{Parameter Setting}

Table 1 shows the major notations used in this paper.

Table 1. Notations.

\begin{tabular}{cl}
\hline Notations & \multicolumn{1}{c}{ Meaning } \\
\hline$a_{1}$ & $\begin{array}{l}\text { The marginal contribution rate of carbon limit to the market price of carbon sink } \\
a_{2}\end{array}$ \\
$b$ & $\begin{array}{l}\text { The influence coefficient of the carbon sink forest's scale on the market price of } \\
\text { The initial market price of forestry carbon sink }\end{array}$ \\
$c_{0}$ & The cost of producing unit product, including necessary means of production, etc. \\
$c_{1}$ & The cost coefficient of carbon sink forest of the forestry enterprise \\
$c_{2}$ & The unit operating cost of the insurance company \\
$E_{g}$ & The average carbon limit level, indicating the stringency of carbon constraint policy \\
$k$ & The scale of carbon sink forest \\
$q_{c}$ & The unit insurance premium of carbon sink forest \\
$r$ & The carbon sequestration rate of unit carbon sink forest \\
$\varepsilon$ & The proportion coefficient of insurance company's compensation for operating cost \\
$\alpha$ & of carbon sink forest when deforestation disaster occurs \\
$\theta_{1}$ & The subsidy rate for forestry enterprise's insurance premium \\
$\theta_{2}$ & The subsidy rate for insurance company \\
$\pi_{c}$ & The expected profit of forestry enterprise \\
$\pi_{i}$ & The expected profit of insurance company
\end{tabular}

\subsection{Basic Assumptions}

Combining the characteristics and business model of forest insurance and forestry carbon sinks, the following three assumptions are proposed:

- Forestry production with the characteristic of uneconomical scale, so the production cost of the carbon sink forest is set as a quadratic production function [37], that is

$$
C\left(q_{c}\right)=c_{0} q_{c}+c_{1} q_{c}^{2}
$$


For the convenience of calculation, $c_{0}=0$ is assumed in this paper without loss of generality [38].

- Both the scale of the carbon sink forest and the average carbon limit level affect the market price of the carbon sink: When the scale of the carbon sink forest expands, the forestry enterprise can provide more forestry carbon sinks, so the price of the forestry carbon sinks will drop. On the other hand, when the carbon limit policy of the government is looser, the market demand of the manufacturing enterprise will be smaller, the price will also drop [39]. Therefore, the carbon sink price is

$$
P_{t}=b-a_{1} E g-a_{2} \varepsilon q_{c}
$$

where $a_{1} E_{g}$ represents the impact of the average carbon limit level on the price and $a_{2} \varepsilon q_{c}$ represents the impact of the scale of the carbon sink forest on the price. In order to continue the study, we assume that $b$ is much larger than $a_{1} E_{g}$ and $a_{2} \varepsilon q_{c}$.

- The operating costs of the insurance company are positively related to the scale of the carbon sink forest insured. We express it with the following formula:

$$
C(r)=c_{2} q_{c}
$$

From the formula, we can see that the larger the scale of the carbon sink forest insured, the greater the costs of relevant surveys, loss assessment, equipment use, and professional employment.

\subsection{Profit Function}

In order to promote the development of the carbon sink market and forest insurance, the government provides certain subsidies to carbon sink insurance. For the convenience of comparison, we consider subsidizing the forest enterprise which insures the carbon sink forest and the insurance company that provides insurance for the carbon sink forest in one model. The subsidies for the forestry enterprise are reflected in the form of premium discounts, and the subsidies for insurance company are reflected in the form of operating expenses ratios.

The profit function of the forestry enterprise is:

$$
\pi_{c}=(1-k)\left(b-a_{1} E_{g}-a_{2} \varepsilon q_{c}\right) \varepsilon q_{c}+k c_{1} q_{c}^{2} \alpha-c_{1} q_{c}^{2}-\left(1-\theta_{1}\right) q_{c} r
$$

where $\left(b-a_{1} E_{g}-a_{2} \varepsilon q_{c}\right) \varepsilon q_{c}$ represents the revenue from the sale of forestry carbon sinks in the absence of deforestation; $\alpha c_{1} q_{c}{ }^{2}$ represents the insurance compensation that the forestry enterprise could get when a deforestation disaster occurs; $k$ is the probability of a deforestation disaster occurrence; $c_{1} q_{c}{ }^{2}$ is the cost of operating carbon sink forests; and $\left(1-\theta_{1}\right) r q_{c}$ is the insurance cost of carbon sink forests, where $\theta_{1}$ represents the premium subsidy rate and $\theta_{1} q_{c} r$ is the government subsidy for forestry enterprise.

The profit function of the insurance company is:

$$
\pi_{i}=q_{c} r-k c_{1} q_{c}^{2} \alpha-\left(1-\theta_{2}\right) c_{2} q_{c}
$$

where $r q_{c}$ represents the insurance company has obtained the whole premium; $\alpha c_{1} q_{c}^{2}$ represents the compensation that the insurance company has to pay in the event of a deforestation disaster; $\left(1-\theta_{2}\right) c_{2} q_{c}$ represents the business cost of operating carbon sink insurance; and $\theta_{2} c_{2} q_{c}$ is the government subsidy for insurance company.

\section{Optimal Strategies of Insurance Parties}

The forestry enterprise and the insurance company compose the Stackelberg game relationship [40]. It is assumed that the insurance company is the dominant party and the forest enterprise is the follower. The backward induction method is used to solve the model. 


\subsection{Optimal Strategy of Forest Enterprise}

The forestry enterprise is aiming at maximizing profits and determines the scale of the carbon sink forest. The following conclusions can be drawn:

Proposition 1. The optimal scale of carbon sink forest of the forestry enterprise is

$$
q_{c}^{*}=\frac{(1-k) B-\left(1-\theta_{1}\right) r}{2 A}
$$

where $A=2(1-k) a_{2} \varepsilon^{2}+2 c_{1}-\left(1+\theta_{1}\right) k \alpha c_{1}>0, B=\left(b-a_{1} E_{g}\right) \varepsilon>0$.

(The proof of Proposition 1 is in Appendix A.1).

It can be seen from Equation (3) that the scale of carbon sink forest is affected by multiple factors such as insurance subsidies, probability of deforestation disasters occurrence, carbon limit levels, and operating costs.

\subsection{Optimal Strategy of Insurance Company}

From the backward induction method, the insurance company's decision-making model is based on the optimal strategy of the forestry enterprise. The decision variable is premium, and the decision model is

$$
\max \pi_{i}(r) \text { s.t.equation }(3)
$$

Proposition 2. The optimal premium satisfies the following formula:

$$
r^{*}=\frac{(1-k) B D}{\left(1-\theta_{1}\right) A}-\frac{\left(1-\theta_{2}\right) c_{2} D}{A}+\frac{k c_{1} \alpha(1-k) B}{A}
$$

where $D=(1-k) a_{2} \varepsilon^{2}+c_{1}-k c_{1} \alpha>0$.

(The proof of Proposition 2 is in Appendix A.2).

It can be seen from Proposition 2 that the insurance company's premiums are affected by many factors such as the probability of deforestation disasters occurrence, carbon limit, and insurance subsidies.

\section{Discussions and Numerical Analysis}

In this section, we will discuss the impact of different subsidy methods, the probability of deforestation disasters occurrence, the average carbon limit level, and the unit cost of operating carbon sink forest on the decision-making and profits of the forest enterprise and insurance company. Moreover, the efficiency of direct subsidies and indirect subsidies in promoting the scale of carbon sink forest and increasing income of the forestry enterprise will be compared. Meanwhile, for illustration purposes, we present a numerical example here. According to the actual situation of the carbon sink transaction and the relevant data in the literature [39], the values of the parameters are shown in Table 2.

Table 2. Parameter values.

\begin{tabular}{lccccccccccc}
\hline \multicolumn{2}{l}{ Parameter $a_{1}$} & $a_{2}$ & $b$ & $c_{1}$ & $c_{2}$ & $E_{g}$ & $k$ & $\alpha$ & $\varepsilon$ & $\theta_{1}$ & $\theta_{2}$ \\
\hline Value & 0.01 & 0.005 & 60 & 25 & 15 & 500 & 0.2 & 0.9 & 0.8 & 0.5 & 0.5 \\
\hline
\end{tabular}




\subsection{Impact of Insurance Subsidies}

Proposition 3. (1) $d q_{c} / d \theta_{1}>0, d q_{c} / d \theta_{2}>0$; (2) $d r / d \theta_{1}>0, d r / d \theta_{2}<0$.

(The proof of Proposition 3 is in Appendix A.3).

Proposition 3 shows that both of direct subsidies and indirect subsidies can increase the scale of carbon sink forest. This is because in the case of direct subsidies, the government shares part of the insurance expenses, which helps to enhance the enthusiasm of operators to insure and encourage them to expand the scale of carbon sink forest. In the case of indirect subsidies, the insurance company's operating costs are reduced. Therefore, the insurance company is willing to carry out the carbon sink forest insurance business with lower insurance premiums, which is conducive to increasing the willingness of the forestry enterprise to participate in insurance and expand the scale of carbon sink forest. The management enlightenment is that the government can raise the premium subsidy rate for the forestry enterprise or the operating subsidy rate for the insurance company properly to expand the scale of carbon sink forest.

Proposition 3 also shows that direct subsidies and indirect subsidies have different effects on forest insurance premiums. Indirect subsidies can help insurance company reduce premiums, while direct subsidies can lead to higher insurance costs. This is because in the case of indirect subsidy, the insurance company's operating costs are reduced, and it is willing to encourage the forestry enterprise to increase the forest scale with lower insurance premiums. However, in the case of direct subsidy, the forestry enterprise's actual costs of insurance are reduced, and the proper increase of the premium rate does not affect the enthusiasm of the forestry enterprise to insure and operate forest, which is consistent with the findings of Qin et al. [27].

In Figures 2 and 3, by numerical analysis, we compare the impact of direct subsidies and indirect subsidies on the scale of carbon sink forest and the profit of forestry enterprise with the same subsidy amount. The results of the numerical analysis are consistent when we change the specific values of the parameters based on relevant references.

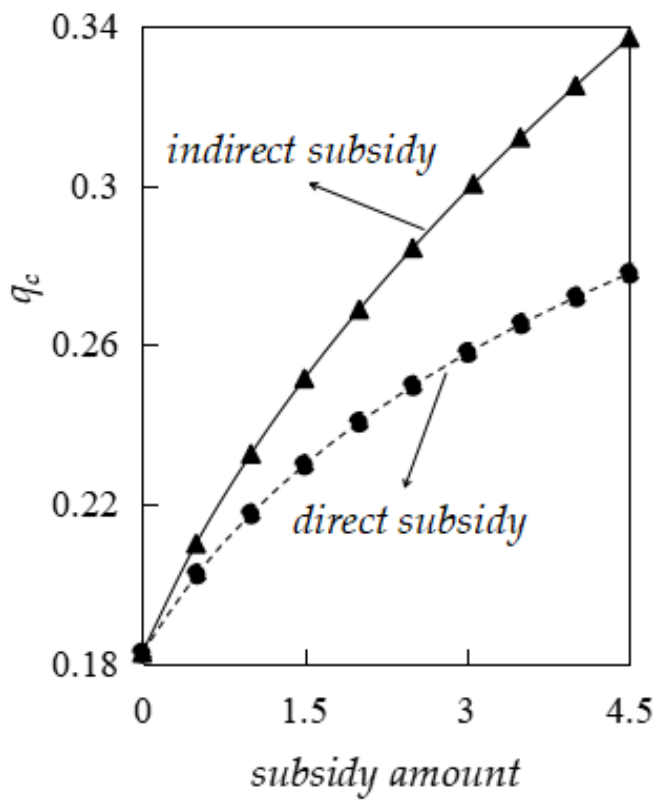

Figure 2. The scale of carbon sink forest. 


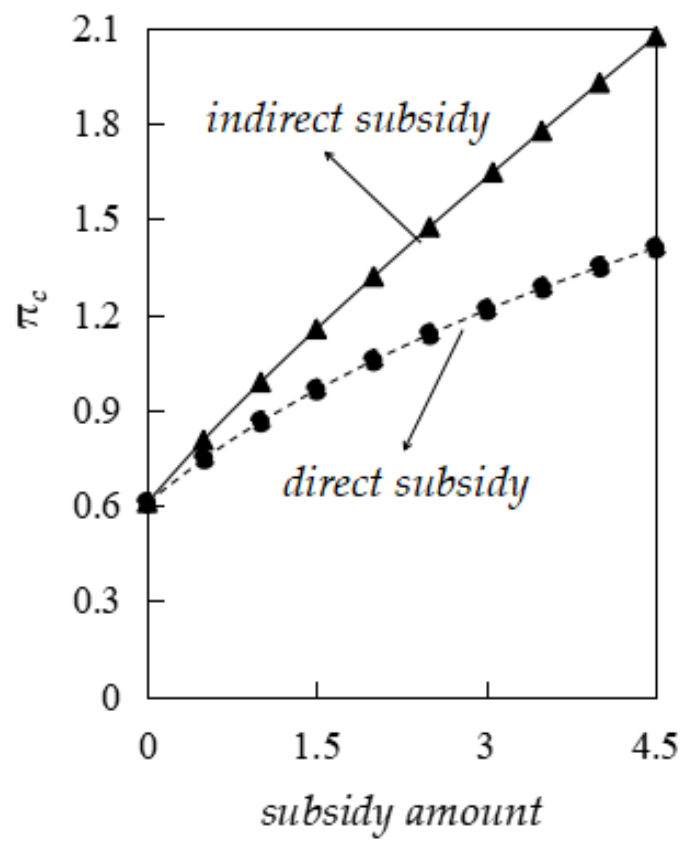

Figure 3. The profit of the forestry enterprise.

It can be seen from Figures 2 and 3 that with the same government subsidy amount, indirect subsidies are better than direct subsidies in promoting the forestry enterprise to increase the scale of carbon sink forest and increasing the profit. This is because Proposition 3 shows that under indirect subsidies, the insurance company reduces premiums to promote the expansion of the scale of carbon sink forest and raise the income of the forestry enterprise. However, under direct subsidies, as the insurance company increases premiums, the effect of direct subsidies on promoting the expansion of carbon sink forest scale and raising the income of the forestry enterprise will be weakened.

It can also be seen from Figures 2 and 3 that the marginal efficiency of government subsidy is declining, whether it is direct subsidy or indirect subsidy, which is also in line with the actual situation of current forest insurance subsidies. Due to this reason, although China's subsidies for forest insurance continue to increase, the benefits that the forestry enterprise gained from the subsidy did not achieve the expected effect of the government. As a result, continued increase in the subsidy ratio will only lead to financial pressure. These findings are consistent with the researches of Sauter [35] and Ma [36]. The management enlightenment is that in order to solve the problem of insufficient supply and demand in the current forest insurance industry, we should consider the differentiated premium subsidy policy and the multilevel subsidy system.

\subsection{Impact of the Probability of Deforestation Occurrence}

Proposition 4. $d q_{c} / d k<0, d r / d k<0$.

(The proof of Proposition 4 is in Appendix A.4).

Proposition 4 shows that as the probability of deforestation occurrence increases, the scale of carbon sink forest of the forestry enterprise will decrease. This is consistent with our intuition.

Proposition 4 indicates an interesting result that the premium level of the insurance company decreases with the probability of deforestation occurrence. The reason is that when the probability of deforestation is high, the management enthusiasm and the willingness to purchase of the forestry enterprise are low. The insurance company will reduce the insurance premiums properly, in order to stimulate the enthusiasm of the forestry enterprise to insure. In addition, the higher risk related to the higher probability of deforestation also plays an important role. Higher risk can lead to poorer 
management which will bring many negative impacts. The management enlightenment is that before managing carbon sink forest, the forestry enterprise should investigate the local climate, soil conditions, and the occurrence of disasters over the years. Then choose the location where the probability of deforestation is low and suitable for managing carbon sink forest.

\subsection{Impact of Carbon Limit Levels}

Proposition 5. $d q_{c} / d E_{g}<0, d r / d E_{g}<0$.

(The proof of Proposition 5 is in Appendix A.5).

Proposition 5 indicates that the scale of carbon sink forest will decrease as the carbon limit increases. This is because the larger the carbon limit, the looser the carbon restraint policy, the less the market demand for forestry carbon sinks. As a result, the carbon sink price will decrease, which leads to the reduction of the scale of carbon sink forest.

Proposition 5 also shows that forest insurance premiums decrease as the carbon limit increases. The reason is as follows: For the insurance company, the higher the carbon limit, the lower the carbon price, which results in the forestry enterprise reducing the scale of carbon sink forest. In order to encourage the forestry enterprise to increase the scale of forest and achieve more premium income, the insurance company needs to lower the level of premiums properly.

The management revelation of Proposition 5 is that when the government implements a proper tight carbon limit policy and lowers the carbon limit level, the benefits are clear: The forestry enterprise will increase the scale of carbon sink forest and the development of the carbon sink forest insurance market can be promoted.

\subsection{Impact of Unit Management Cost of Insurance Company}

Proposition 6. $d q_{c} / d c_{2}<0, d r / d c_{2}>0$.

(The proof of Proposition 6 is in Appendix A.6).

Proposition 6 indicates that the scale of carbon sink forest will decrease with the unit operating cost of the insurance company. On the contrary, the insurance premium will increase with the unit operating cost. For the insurance company, it is obvious that to ensure its profitability, higher unit cost of operating carbon sink insurance leads to higher premium price. With the increase of premium, the cost of purchasing carbon sink forest insurance has increased. As a result, the forestry enterprise will reduce the scale of carbon sink forest.

The management inspiration of Proposition 6 is that subsidizing the operating costs of insurance company is not only conducive to reducing the price level of premium, but also beneficial to increasing the scale of carbon sink forest. So, indirect subsidy is an effective method.

\subsection{Impact of Insurance Compensation Ratio}

Proposition 7. $d q_{c} / d \alpha>0, d r / d \alpha>0$.

(The proof of Proposition 7 is in Appendix A.7).

Proposition 7 indicates that both the scale of the carbon sink forest and the insurance premium increase as the proportion of insurance compensation increases. This is because for the forest enterprise, the greater the proportion of compensation of the insurance company, the higher the amount of compensation it can obtain after the deforestation disaster, which is conducive to expanding the scale of the carbon sink forest. However, when the amount of compensation is great, the insurance company has to increase its insurance premium to maintain profit level. 


\section{Conclusions}

We take the forestry carbon sink as the insurance target. By constructing the Stackelberg game model, we study the carbon sink forest management strategy under the forest insurance mechanism and analyze the impacts of government subsidies, probability of deforestation disasters occurrence, carbon limit levels on the decision-making, and profit of the forestry enterprise and insurance company. Moreover, the efficiency of direct subsidies and indirect subsidies in promoting the scale of carbon sink forest and increasing the income of forestry enterprise are compared. The results show that although direct subsidies can encourage the forestry enterprise to expand the scale of carbon sink forest and achieve higher income, it will also lead the insurance company to increase its premiums, which will have a bad influence on the enthusiasm of both parties. On the other hand, indirect subsidies guide the insurance company to lower the premium level and greatly increase the forestry enterprise's willingness to insure by reducing the pressure on the operating costs of insurance company. In addition, in the case of the same number of premium subsidies, indirect subsidies are more effective than direct subsidies in promoting forestry enterprise to expand forest scale and increase income. The scale of carbon sinks forest and forest insurance premium decrease with carbon limit. The scale of carbon sink forest will decrease while the insurance premium will increase with the unit operating cost of insurance company.

In this article, the financial constraints of forestry enterprise have not been considered. However, this might be a common problem in operation. Under the financial constraints and insurance mechanism, how does the forestry enterprise use forestry carbon sinks to finance? Is there a proper carbon sink forest production risk sharing mechanism to promote the operation of carbon sink forest? These can be the direction for further researches.

Author Contributions: H.P. set up the framework of this paper and revised the paper many times; Y.S. did the calculations of the models, collected the data and examples, analyzed the data, and wrote the first draft of the paper.

Funding: The research is supported by the National Social Science Foundation of China (Grant NO. 17BGL236).

Conflicts of Interest: The authors declare no conflict of interest. The funders had no role in the design of the study; in the collection, analyses, or interpretation of data; in the writing of the manuscript, or in the decision to publish the results.

\section{Appendix A}

\section{Appendix A.1. Proof of Proposition 1}

From Equation (1), we can derive that

$$
\begin{gathered}
\frac{d \pi_{c}}{d q_{c}}=(1-k) B-2 A-\left(1-\theta_{1}\right) r \\
\frac{d^{2} \pi_{c}}{d q_{c}{ }^{2}}=-2 A<0
\end{gathered}
$$

Therefore, $\pi_{c}\left(q_{c}\right)$ is a concave function about $q_{c}$. Thus, $d \pi_{c} / d q_{c}=0$, we can obtain Equation (3). $A=2(1-k) a_{2} \varepsilon^{2}+2 c_{1}-\left(1+\theta_{1}\right) c_{1}=2(1-k) a_{2} \varepsilon^{2}+\left[2-\left(1+\theta_{1}\right) k \alpha\right] c_{1}$, because, $0<k<1$, $0<\theta_{1}<1,0<\alpha<1$, so, $1-k>0,2-\left(1+\theta_{1}\right) k \alpha>0$. And we can derive that $A>0$.

$B=\left(b-a_{1} E_{g}\right) \varepsilon, \varepsilon>0$, because we assume that $b$ is much larger than $a_{1} E_{g}$ in basic assumptions, so, $\left(b-a_{1} E_{g}\right) \varepsilon>0$. And we can derive that $B>0$. 
Appendix A.2. Proof of Proposition 2

We bring the optimal solution of $q_{c}$ into Equation (2). Then deriving the formula and we can find that

$$
\begin{gathered}
\frac{d \pi_{i}}{d r}=\frac{(1-k) B-2\left(1-\theta_{1}\right) r}{2 D}-\frac{\left[\left(1-\theta_{1}\right)^{2} r-(1-k)\left(1-\theta_{1}\right) B\right] k c_{1} \alpha}{2 D^{2}}+\frac{\left(1-\theta_{1}\right)\left(1-\theta_{2}\right) c_{2}}{2 D} \\
\frac{d^{2} \pi_{i}}{d r^{2}}=-\frac{1-\theta_{1}}{D}-\frac{\left(1-\theta_{1}\right)^{2} k c_{1} \alpha}{2 D^{2}}<0
\end{gathered}
$$

Therefore, $\pi_{i}(r)$ is a concave function about $r$. Thus, $d \pi_{i} / d r=0$, we can obtain Equation (4).

$D=(1-k) a_{2} \varepsilon^{2}+c_{1}-k c_{1} \alpha=(1-k) a_{2} \varepsilon^{2}+(1-k \alpha) c_{1}$, because, $0<k<1,0<\alpha<1$, so, $1-k>0$, $1-k \alpha>0$. And we can derive that $D>0$.

Appendix A.3. Proof of Proposition 3

From Equations (3) and (4), we can derive that

$$
\frac{d q_{c}}{d \theta_{1}}=\frac{k c_{1} \alpha(1-k) B}{2 A^{2}}+\frac{\left(1-\theta_{2}\right) c_{2} D}{A^{2}}>0, \frac{d q_{c}}{d \theta_{2}}=\frac{\left(1-\theta_{1}\right) c_{2}}{2 A}>0,
$$

From Equation (4), it is easy to find that

$$
\begin{gathered}
\frac{d r}{d \theta_{1}}=\frac{(1-k) B D}{\left(1-\theta_{1}\right)^{2} A}+\frac{k c_{1} \alpha(1-k) B D}{\left(1-\theta_{1}\right) A^{2}}+\frac{k c_{1} \alpha\left(1-\theta_{2}\right) c_{2} D}{A^{2}}+\frac{\left[k c_{1} \alpha(1-k) B\right] k c_{1} \alpha}{A^{2}}>0 \\
\frac{d r}{d \theta_{2}}=-\frac{c_{2} D}{A}<0 .
\end{gathered}
$$

Appendix A.4. Proof of Proposition 4

From Equations (3) and (4), we can derive that

$$
\frac{d q_{c}}{d k}=\frac{\left[\left(1+\theta_{1}\right) c_{1} \alpha-2 c_{1}\right] B}{2 A^{2}}-\frac{\left(1-\theta_{1}\right)\left(1-\theta_{2}\right) c_{2}\left[2 a_{2} \varepsilon^{2}+\left(1+\theta_{1}\right) c_{1} \alpha\right]}{2 A^{2}}<0
$$

From Equation (4), it is easy to find that

$$
\begin{aligned}
& \frac{d r}{d k}=\quad-\frac{B\left[D-\left(1-\theta_{1}\right)(1-k) c_{1} \alpha\right]}{\left(1-\theta_{1}\right) A}-\frac{c_{1} \alpha(1-k)\left(a_{2} \varepsilon^{2}+c_{1}\right) B}{A^{2}} \\
& -\frac{c_{1} \alpha\left(1-\theta_{1}\right)\left(1-\theta_{2}\right) c_{2}\left(a_{2} \varepsilon^{2}+c_{1}\right)}{A^{2}}-\frac{c_{1} \alpha\left[2 k c_{1}-\left(1+\theta_{1}\right) k c_{1} \alpha\right] B}{A^{2}}<0
\end{aligned}
$$

Appendix A.5. Proof of Proposition 5

From Equations (3) and (4), we can derive that

$$
\frac{d q_{c}}{d E_{g}}=-\frac{a_{1} \varepsilon(1-k)}{2 A}<0
$$

From Equation (4), it is easy to find that

$$
\frac{d r}{d E_{g}}=-\frac{(1-k) a_{1} \varepsilon D}{\left(1-\theta_{1}\right) A}-\frac{k c_{1} \alpha(1-k) a_{1} \varepsilon}{A}<0
$$


Appendix A.6. Proof of Proposition 6

From Equations (3) and (4), we can derive that

$$
\frac{d q_{c}}{d c_{2}}=-\frac{\left(1-\theta_{1}\right)\left(1-\theta_{2}\right)}{2 A}<0
$$

From Equation (4), it is easy to find that

$$
\frac{d r}{d c_{2}}=\frac{\left(1-\theta_{2}\right) D}{A}>0
$$

Appendix A.7. Proof of Proposition 7

From Equations (3) and (4), we can get that

$$
q_{c}=\frac{(1-k) B-\left(1-\theta_{1}\right)\left(1-\theta_{2}\right) c_{2}}{2 A}>0
$$

Because, $A=2(1-k) a_{2} \varepsilon^{2}+2 c_{1}-\left(1+\theta_{1}\right) k \alpha c_{1}>0$, so, $(1-k) B-\left(1-\theta_{1}\right)\left(1-\theta_{2}\right) c_{2}>0$.

From Equations (3) and (4), we can derive that

$$
\frac{d q_{c}}{d \alpha}=\frac{\left[(1-k) B-\left(1-\theta_{1}\right)\left(1-\theta_{2}\right) c_{2}\right]\left(1+\theta_{1}\right) k c_{1}}{2 A^{2}}>0
$$

From Equation (4), we can get that

$$
\frac{d r}{d \alpha}=\frac{k c_{1}\left[(1-k) a_{2} \varepsilon^{2}+c_{1}\right]\left[(1-k) B-\left(1-\theta_{1}\right)\left(1-\theta_{2}\right) c_{2}\right]}{A^{2}}>0
$$

\section{References}

1. Zhou, T.; Shi, P.; Jia, G.; Dai, Y.; Zhao, X.; Shangguan, W.; Du, L.; Wu, H.; Luo, Y. Age-dependent forest carbon sink: Estimation via inverse modeling. J. Geophys. Res. Biogeosci. 2015, 120, 2473-2492. [CrossRef]

2. Woodbury, P.B.; Smith, J.E.; Heath, L.S. Carbon sequestration in the US forest sector from 1990 to 2010. For. Ecol. Manag. 2007, 241, 14-27. [CrossRef]

3. Lin, B.Q.; Ge, J.M. Valued forest carbon sinks: How much emissions abatement costs could be reduced in China. J. Clean. Prod. 2019, 224, 455-464. [CrossRef]

4. She, W.; Wu, Y.; Huang, H.; Chen, Z.; Cui, G.; Zheng, H.; Guan, C.; Chen, F. Integrative analysis of carbon structure and carbon sink function for major crop production in China's typical agriculture regions. J. Clean. Prod. 2017, 162, 702-708. [CrossRef]

5. Birdsey, R.A. Carbon Accounting Rules and Guidelines for the United States Forest Sector. J. Environ. Qual. 2006, 35, 1518-1524. [CrossRef] [PubMed]

6. Gren, I.M.; Aklilu, A.Z.; Zeleke, A.A. Policy design for forest carbon sequestration: A review of the literature. For. Policy Econ. 2016, 70, 128-136. [CrossRef]

7. Valade, A.; Bellassen, V.; Magand, C.; Luyssaert, S. Sustaining the sequestration efficiency of the European forest sector. For. Ecol. Manag. 2017, 405, 44-55. [CrossRef]

8. Li, P.; Zhu, J.; Hu, H.; Guo, Z.; Pan, Y.; Birdsey, R.; Fang, J. The relative contributions of forest growth and areal expansion to forest biomass carbon. Biogeosciences 2016, 13, 375-388. [CrossRef]

9. Noormets, A.; Epron, D.; Domec, J.; McNulty, S.; Fox, T.; Sun, G.; King, J. Effects of forest management on productivity and carbon sequestration: A review and hypothesis. For. Ecol. Manag. 2015, 355, 124-140. [CrossRef]

10. Daniels, T.L. Integrating Forest Carbon Sequestration into a Cap-and-Trade Program to Reduce $\mathrm{Net}^{\mathrm{CO}_{2}}$ Emissions. J. Am. Plan. Assoc. 2010, 76, 463-475. [CrossRef]

11. Sun, M.J.; Peng, H.J.; Cong, J. A review of carbon finance and forestry carbon sink project financing. Issues For. Econ. 2018, 38, 90-98. 
12. Boscolo, M.; Van Dijk, K.; Savenije, H. Financing Sustainable Small-Scale Forestry: Lessons from Developing National Forest Financing Strategies in Latin America. Forest 2010, 1, 230-249. [CrossRef]

13. Shu, S.M.; Zhu, W.Z.; Wang, W.Z.; Jia, M.; Zhang, Y.Y.; Sheng, Z.L. Effects of tree size heterogeneity on carbon sink in old forests. For. Ecol. Manag. 2019, 432, 637-648. [CrossRef]

14. Jiang, L.H.; Zhao, W.; Lewis, B.J.; Wei, Y.W.; Dai, L.M. Effects of management regimes on carbon sequestration under the Natural Forest Protection Program in northeast China. J. For. Res. 2018, 29, 1187-1194. [CrossRef]

15. Gao, S.; Zhou, T.; Zhao, X.; Wu, D.; Li, Z.; Wu, H.; Du, L.; Luo, H. Age and climate contribution to observed forest carbon sinks in East Asia. Environ. Res. Lett. 2016, 11, 034021. [CrossRef]

16. Lin, B.Q.; Ge, J.M. Carbon sinks and output of China's forestry sector: An ecological economic development perspective. Sci Total Environ. 2019, 655, 1169-1180. [CrossRef]

17. Zhang, C.; Ju, W.; Chen, J.M.; Wang, X.; Yang, L.; Zheng, G. Disturbance-induced reduction of biomass carbon sinks of China's forests in recent years. Environ. Res. Lett. 2015, 10, 114021. [CrossRef]

18. Magnússon, R.Í.; Tietema, A.; Cornelissen, J.H.; Hefting, M.M.; Kalbitz, K. Tamm Review: Sequestration of carbon from coarse woody debris in forest soils. For. Ecol. Manag. 2016, 377, 1-15. [CrossRef]

19. Xu, B.; Pan, Y.; Plante, A.F.; Johnson, A.; Cole, J.; Birdsey, R. Decadal change of forest biomass carbon stocks and tree demography in the Delaware River Basin. For. Ecol. Manag. 2016, 374, 1-10. [CrossRef]

20. Yang, H.Q.; Li, X. Potential variation in opportunity cost estimates for REDD plus and its causes. For. Policy. Econ. 2018, 95, 138-146. [CrossRef]

21. Subak, S. Replacing carbon lost from forests: An assessment of insurance, reserves, and expiring credits. Clim. Policy 2003, 3, 107-122. [CrossRef]

22. Luyssaert, S.; Schulze, E.D.; Börner, A.; Knohl, A.; Hessenmöller, D.; Law, B.E.; Ciais, P.; Grace, J. Old-growth forests as global carbon sinks. Nature 2008, 455, 213-215. [CrossRef]

23. Phelan, L.; Henderson-Sellers, A.; Taplin, R. Climate change, carbon prices and insurance systems. Int. J. Sustain. Dev. World Ecol. 2010, 17, 95-108. [CrossRef]

24. Couture, S.; Reynaud, A. Forest management under fire risk when forest carbon sequestration has value. Ecol. Econ. 2011, 70, 2002-2011. [CrossRef]

25. Cairns, R.D.; Lasserre, P. Reinforcing economic incentives for carbon credits for forests. For. Policy Econ. 2004, 6, 321-328. [CrossRef]

26. Qin, T.; Deng, J.; Pan, H.; Gu, X. The effect of coverage level and premium subsidy on farmers' participation in forest insurance: An empirical analysis of forest owners in Hunan Province of China. J. Sustain. For. 2016, 35, 191-204. [CrossRef]

27. Qin, T.; Gu, X.; Tian, Z.; Pan, H.; Deng, J.; Wan, L. An empirical analysis of the factors influencing farmer demand for forest insurance: Based on surveys from Lin'an County in Zhejiang Province of China. J. For. Econ. 2016, 24, 37-51. [CrossRef]

28. Peng, H.J.; Pang, T. Optimal strategies for a three-level contract-farming supply chain with subsidy. Int. J. Prod. Econ. 2019, 216, 274-286. [CrossRef]

29. Pinheiro, A.; Ribeiro, N. Forest property insurance: An application to Portuguese wood lands. Int. J. Sustain. Soc. 2013, 5, 284-295. [CrossRef]

30. Liesivaara, P.; Myyrä, S. The demand for public-private crop insurance and government disaster relief. J. Policy Model. 2017, 39, 19-34. [CrossRef]

31. Luo, L.; Wang, Y.; Qin, L. Incentives for promoting agricultural clean production technologies in China. J. Clean. Prod. 2014, 74, 54-61. [CrossRef]

32. Qin, T.; Gu, X.S.; Li, J.Y.; Deng, J. Literature Review and Research Prospects in Forest Insurance Subsidies Policy. J. Agro. For. Econ. Manag. 2017, 16, 310-315.

33. Zheng, B.; Gao, L. Evaluation of efficiency of forest insurance premium subsidies-Based on se-dea model and malmquist index. Res. Dev. Market. 2019, 35, 7-12.

34. Wang, C.; Nie, P.Y.; Peng, D.H.; Li, Z.H. Green insurance subsidy for promoting clean production innovation. J. Clean. Prod. 2017, 148, 111-117. [CrossRef]

35. Sauter, P.A.; Möllmann, T.B.; Anastassiadis, F.; Mußhoff, O.; Möhring, B. To insure or not to insure? Analysis of foresters' willingness-to-pay for fire and storm insurance. For. Policy Econ. 2016, 73, 78-89. [CrossRef]

36. Ma, N.; Zuo, Y.; Liu, K.; Qi, Y. Forest insurance market participants' game behavior in China: An analysis based on tripartite dynamic game model. J. Ind. Eng. Manag. 2015, 8, 1533-1546. [CrossRef] 
37. Niu, B.Z.; Jin, D.L.; Pu, X.J. Coordination of channel members' efforts and utilities in contract farming operations. Eur. J. Oper. Res. 2016, 255, 869-883. [CrossRef]

38. Ye, F.; Huang, J.H.; Lin, Q. The optimal production strategies of the farmer in contract-farming supply chain under capital constraint. Syst. Eng. Theory Pract. 2017, 37, 1467-1478.

39. Sun, M.; Peng, H.J.; Wang, S. Cost-Sharing Mechanisms for a Wood Forest Product Supply Chain under Carbon Cap-and-Trade. Sustainability 2018, 10, 4345. [CrossRef]

40. Peng, H.J.; Pang, T.; Cong, J. Coordination contracts for a supply chain with yield uncertainty and low-carbon preference. J. Clean. Prod. 2018, 205, 291-302. [CrossRef]

(C) 2019 by the authors. Licensee MDPI, Basel, Switzerland. This article is an open access article distributed under the terms and conditions of the Creative Commons Attribution (CC BY) license (http://creativecommons.org/licenses/by/4.0/). 